\title{
Maus: Narrating Life through Archiving of Autotopographical Objects
}

\author{
Lakshani Willarachchi \\ Department of Languages, General Sir John Kotelawala Defence University, Sri Lanka
}

Copyright@2018 by authors, all rights reserved. Authors agree that this article remains permanently open access under the terms of the Creative Commons Attribution License 4.0 International License

\begin{abstract}
Autotopographical objects play a pivotal role in life narratives, and the graphic novel Maus: A Survivor's Tale, by Art Spiegelman is no exception. Based on a close reading and textual analysis of the text, the present study analyses the autotopographical objects in the novel under four categories: photographs, masks, miscellaneous objects of everyday life, and lost autotopographical objects, with a view to expounding the nexus between life narration and autotopographical objects. It was found that autotopographical objects in Maus show how objects enable the life narratives to be constructed and viewed in varied lights, how the autotopographical objects become an embodiment of lives narrated, the significance of the artist's involvement in contextualizing these objects and providing supplementary details, metamorphosis of everyday objects into autotopographical objects in the course of life narration, and the significance and impact of absent autotopographical objects in creating gaps in life narratives while adding layers of meaning through the dynamics of absence and presence.
\end{abstract}

Keywords Maus, Autotopographical Objects, Life Narration, Graphic Novel

\section{Introduction}

Often in life narratives references are made to various objects as autotopographical objects which help create a physical map of memories and experiences narrated, i.e. an autotopography. These objects are often projected as parts of the life that is narrated, and at the same time, these are crucial for understanding the narrative.

According to Joanne Karpinski [1], “some possessions extend their biographical role by claiming affiliation between the biographical subject and a personally significant group," and she further argues that certain objects are used to "embody a self-aware and deliberate connection between subject and life narrative”. Karpinski’s claim also highlights the fact that this connection between an auto/biographical artefact and an auto/biographical subject is a deliberate action, resulting from the self-awareness of the author. Viewed in this light, it is possible to claim that such autotopographical objects are brought into the narrative to add further insight to the life that is being narrated.

The present study aims to expound such claims via textual analysis of the graphic novel, Maus: A Survivor's Tale by Art Spiegelman. The analysis, based on a close reading of the text, specifically looks into the use of autotopographical objects vis-à-vis life narration in the novel.

Consisting of two volumes written in the 1980s and 1990s by Art Spiegelman (an American cartoonist of Jewish origin) Maus is a story of tragedy, survival and trauma. The two volumes, 'My Father Bleeds History' and 'And Here My Troubles Began', narrate not only the lives of Vladek and Anja Spiegelman, but also that of Artie Spiegelman, the writer himself. Considered as part of 'the explosion' in experimenting life narrative media in the 1980s and 1990s [2], the graphic novel also stands as a shared history of Jewish people victimized during World War II. Thus, Maus becomes a text containing multiple life narratives. However, the primary narrative is that of Vladek's life since the entire is text is based on the recordings of his recollections.

\section{Autotopography and Life Narration in Maus}

As stressed by Hilary Chute, "Maus is about archives, and it also itself does the work of archiving” [3]. It is through the archiving of autotopographical objects Artie and Vladek construct the life narratives, share, and attempt to overcome trauma, which is why autotopographical objects are made to embody a self-aware and deliberate connection between the auto/biographical subject and life narrative. 
Similar to Alison Bechdel's Fun Home, Maus too makes numerous references to artefacts or autotopographical objects visually as well as verbally. In fact, one of the key idiosyncrasies of its central character, Vladek Spiegelman, is his obsession of archiving, i.e. hoarding of various objects ranging from gold and money to scraps of paper and wire. In the pursuit of finding how autotopographical objects enrich the narrative and their significance, this study will focus on the following in the course of the analysis: photographs, masks, miscellaneous objects of everyday life, and lost autotopographical objects.

\subsection{Photographs}

When looking at the photographs in this graphic novel, it is evident that though Spiegelman may have had access to a larger collection of family photographs only three photographs (see Figure 1) appear in the entire novel; namely, young Art with Anja (his mother), Richieu (his brother who died at the age of six), and Vladek (his father) posing for a souvenir photograph after surviving the holocaust.

The photograph with Anja and young Art (near Trojan Lake, NY) depict a happy mother and son, and it can be interpreted as a symbol of life having regained normalcy in the postwar context. In terms of Artie's life narrative also, this depicts an idyllic moment in his childhood prior to the demise of Anja, a victim of trauma. The photograph featuring Richieu, Art's elder brother who was killed during the holocaust, is a presence in absence. The presence of the photograph is a constant reminder of the loss, and it is related to the suffering undergone by the Spiegelmans. It also stands as a biographical footprint of Richieu, who was (un)known to Artie, in the family life narrative. The souvenir photograph of Vladek resonates with the idea of a 'survivor's tale'. It is the first photograph of Vladek as a free man taken on his way from the concentration camp, and he is wearing the uniform of Jewish prisoners, which has already become a memento of an era of horror.

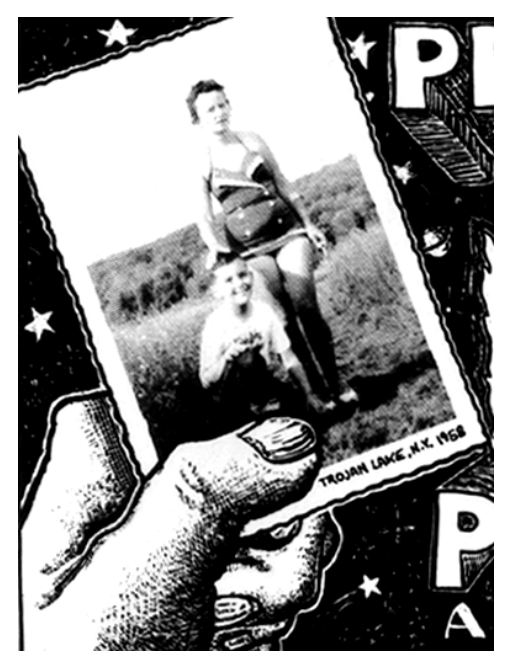

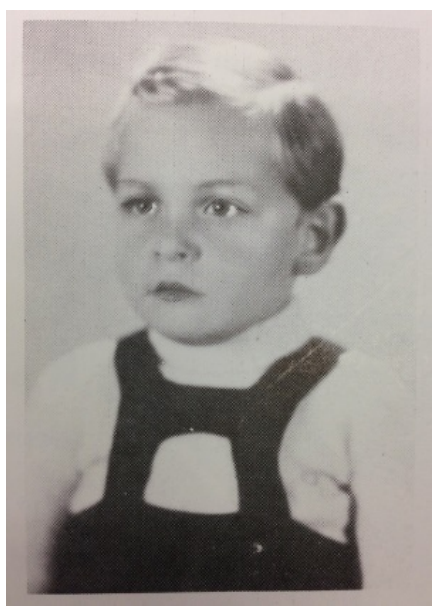

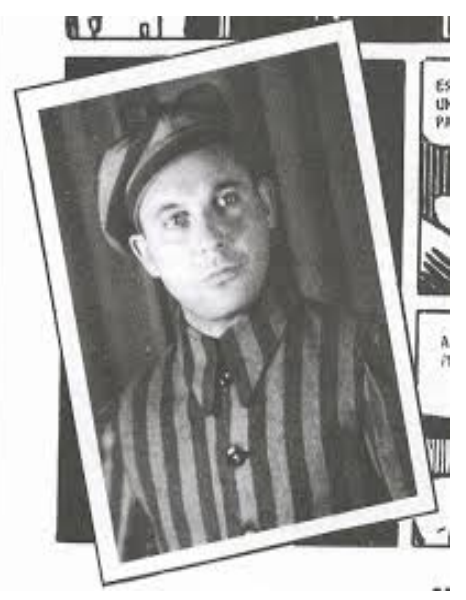

Figure 1. The three photographs in Maus

As observed by Marianne Hirsch [4], "Photograph's relation to loss and death is not to mediate the process of individual and collective memory but to bring the past back in the form of a ghostly revenant, emphasizing, at the same time, its immutable and irreversible pastness and irretrievability" (p. 20).

Seeing the photographs of the three deceased members of the Spiegelman family, the viewers may feel "immutable and irreversible pastness and irretrievability", but more importantly their presence act as 'proof' of the incidents and lives narrated in Maus and signify the novel's 'truthfulness', thus strengthening the autobiographical pact.

Speaking in terms of auto/biography, Karpinski says that photographs "represent elements of...life pictorially" [1]. In my opinion, photographs archive elements of both personal and public life, as can be explained by analyzing Vladek's souvenir photograph. For Vladek it is celebrating his survival, for Anja it is proof of Vladek having survived, for the readers it is evidence of Vladek being there and having survived, for Jewish community it may mean the end of an era that dehumanized them (human face in the photograph instead of the mouse face), but for the world at large it probably signifies the end of the World War II. At another level, it reveals the commercial element of the 
modern world where somebody was quick to realize that 'souvenir photos' have the potential to become a lucrative source of income. This would also lead to the question whether reducing the camp uniform which connotes the Nazi regime, indescribable sufferings at concentration camps, dehumanizing of Jewish prisoners etc. to a mere commercial object is ethical. Does it then take the sacred element of life narration away?

However, the courage, determination and pride stamped on Vladek's face (seen as a mouse in all other frames of the novel) bears testimony to the details of his courage and determination conveyed to the readers in the course of the narrative. Nevertheless, it does not reveal the trauma which will affect him for the rest of his life, and so I would argue that though an autotopographical object may embody a connection between the subject and life narrative it would fail to reveal certain aspects of the life narrative unless the artist intervenes by providing supplementary details, and positions the artefact in the appropriate context in the process of archiving.

\subsection{Masks}

Secondly, the significance of the masks in the novel is discussed. For Spiegelman, the "most shockingly relevant anti-Semitic work ....was the 'Eternal Jew'...with a title card that said 'Jews are the rats' or the 'vermin of mankind' This made it clear...that this dehumanizing was at the heart of the killing project" [5], and this prompted him to draw the Jews as mice, Nazis as cats, Poles as pigs etc. with animal faces and human bodies. The cat and mouse metaphor also highlighted the persecution of the Jews by the Nazis, and is also seen as "a conception of unequal human relations" [6] There are some instances in the text where characters wear different masks; Vladek wears a pig mask when he conceals his Jewish identity by pretending to be a Pole, and Artie himself is shown putting on his Mouse mask when writing Maus (See Figure 2).

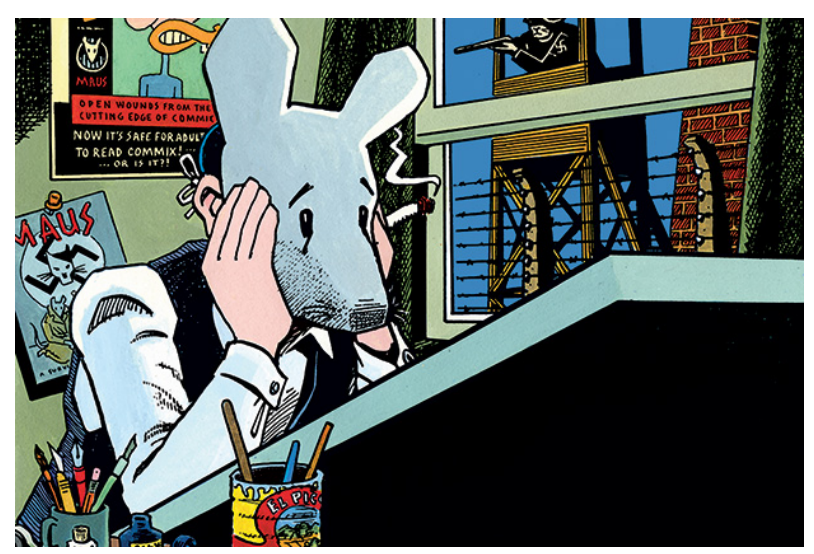

Figure 2. Artie wearing the Mouse mask when writing

For Vladek it is a survival strategy, but for Artie it is a mode of connecting with Jewish identity. Specifically, it is a means of getting in touch with his roots. Commenting on this Hirsch [4] says, "Spiegelman would like to make it clear throughout his books that his representational choices are just that-choices- and that identities are assumed rather than given” (p. 28). But this is contestable since in Maus certain identities are given and not assumed. The Jews, when portrayed as vermin by the Nazis, did not have a choice but to bear the identity which was forced on them; a claim that can be strengthened by the fact that even after the holocaust all Jewish characters in Maus are drawn as mice. A mask stands for concealing or assuming a different identity, but in Maus they are used to signify identity as well, so that it becomes an integral part of life narrative. Spiegelman's choice here enables masks to embody the connection between the individuals and life narrative.

\subsection{Everyday Objects}

The third category is miscellaneous everyday objects which are used to build a rapport between the auto/biographical subject and the life narrative. Vladek is often seen hoarding objects and autotopographical objects, especially in the post-holocaust period. On his way to the bank with Artie, for instance, he picks up a piece of discarded telephone wire and says “Inside it's little wires. It's good for tying things" [7]. At this point, this seemingly trivial act signifies nothing but a hoarding instinct since Vladek's present life is not one of hardships. Artie, and even the readers, wonder what use could Vladek possibly have of the wires, as the novel indicates that Vladek is well-off and leads a comfortable life in the aftermath of the holocaust. It is much later (in Vol. 2) we learn the biographical significance of this action, when Vladek recounts his camp experience where one prisoner was given an oversized pair of pants and “...he had not even a piece of string to make a belt", and prayed "Please God...Help me find a piece of string" [8]. The urge to collect whatever that may become useful at a later day arises from his holocaust experiences, and therefore it cannot be defined simply as hoarding; it reflects a survival strategy which has now become a habit. Hence it is evident that the wires which can be used for 'tying' things embody in them a shard of Vladek's life narrative. Thus the novel shows how everyday objects metamorphose into autotopographical objects in the course of life narration.

Similarly, Vladek's obsession in counting his pills and crackers can be traced back to the ration system at Nazi camps and how he learnt to survive by stashing a part of the meager rations away for future use whenever possible. When reproached by Artie, he says "I cannot forget it. Ever since Hitler I don't like to throw out even a crumb” [7]. Though this obsession with archiving objects can be seen as a result of his holocaust experiences, it can also be argued that he became a survivor because he always had this character trait and it only got accentuated during the Nazi regime. This observation can be supported by the fact that Vladek was always perceived by his people as a 
meticulous, shrewd, and business-oriented person who plans and 'saves' for the future. This may lead to the question whether Spiegelman's portrayal of his father's obsession of archiving as an idiosyncrasy reinforces the stereotypical notion of the hoarding, miserly Jew? Or in contrast, it could be seen as an attempt to highlight frugality and planning as strengths of the Jewish community which have been distorted into avarice and other vices in the Nazi interpretation and portrayal of Jews. Thus, objects enable the life narratives to be constructed and viewed in varied lights.

In the section following Vladek's death in volume 1, Artie is depressed and is at a loss as to how to complete the second volume of the novel, "Lately I've been feeling depressed” [8]. He has drawn himself as too small for the chairs he sits during this time (See Figure 3). Unlike in former frames where he is comfortable in the chairs and is in control of his life and writing, his lack of confidence and increasing vagueness are manifested through the chairs which thus embody a self-aware and deliberate connection between subject and life narrative.

\subsection{Lost Autotopographical Objects}

The fourth category is lost autotopographical objects. These play a significant role in the novel. As mentioned earlier, "Maus is about archives and...archiving" [9] and these lost autotopographical objects mark the gaps in archives. The lost diaries of Anja are seen versus the archived tape records of Vladek's narrative. Anja's diaries and letters, destroyed by Vladek in a moment of despair, signify the absence of her graphically encoded life narrative. Artie accuses his father of being a 'murderer', which shows how 'life' is attributed to inanimate diaries, i.e. autotopographical objects, because of their embodiment of Anja's memories and autobiographical narrative. Artie, not realizing that it was Vladek's attempt to overcome trauma, blames him for that deliberate act of destruction of a link to Anja's life narrative. In the absence of her narrative, Anja herself becomes an object within the narratives of Vladek and Artie, "In their memory she is mystified, objectified, shaped to the needs and desires of the one who remembers-whether it is Art or Vladek" [4].
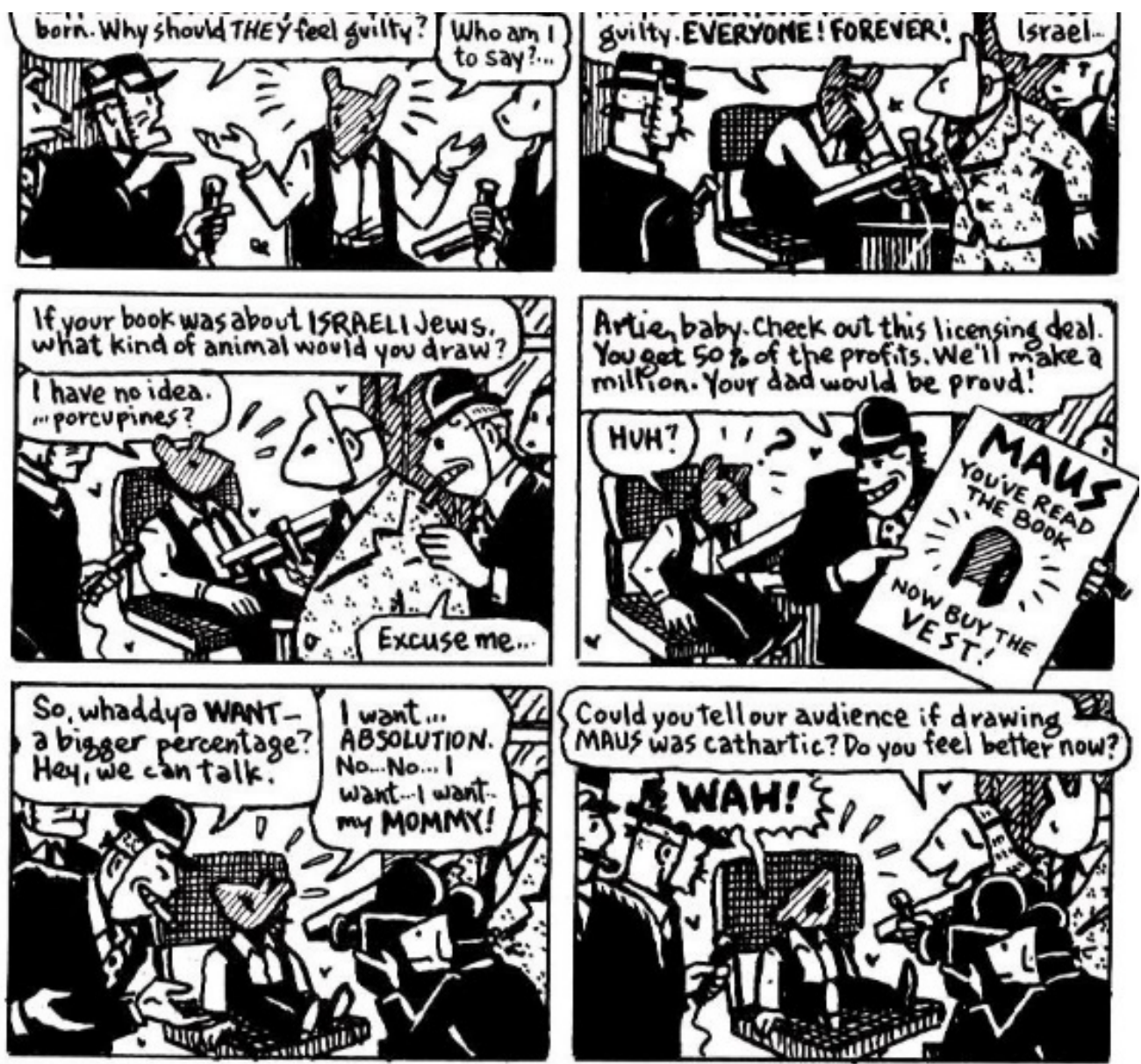

Figure 3. Too small for his chair: Depiction of Art's depressed state of mind 
The process of archiving brings Artie and Vladek together in sharing and attempting to overcome trauma, though it initially creates a rupture in their relationship. Cathy Caruth writes in Unclaimed Experience: Trauma, Narrative and History, that voicing of trauma can be viewed:

"...not as the story of the individual in relation to events of his own past but as the story of the way in which one's own trauma is tied up with the trauma of another, the way in which trauma may lead...to the encounter with another, through the very possibility and surprise of listening to another's wound" [5].

This is what happens when Artie and Vladek construct the life narratives through the process of archiving. They make meaning of the auto/biographical subjects and narratives through these. A case in point is 'Prisoner on the Hell Planet: A Case History', a graphic novel inside the graphic novel Maus, which narrates Anja's suicide and its traumatic impact on Artie, which is later read by Vladek. This projects how Vladek's trauma is related to Artie's where he 'listens to another's wound'. The 'comix' reflecting young Artie's mind-prison is an expression of trauma and guilt, and it testifies how the horror of the holocaust is passed on to the next generation as well. According to Stanislav Kolar [10], "the creation of this comix itself represented an enactment of the painful family history that might have therapeutic effects but that also caused the tension between him and his father after Vladek had accidentally discovered his son's juvenile work” (p. 230). So the process of archiving Anja's life not only reflects upon the lives of the two re-constructors of the narrative, but also has a direct impact on the relationship between the father and the son.

\section{Conclusions}

In conclusion it can be deduced that autotopographical objects are central to the graphic novel Maus, since they embody a self-aware and deliberate connection between auto/biographical subject and life narrative in the process of creating auto/biographical life narratives. This process has also enabled the life writers to share and attempt to overcome trauma. Autotopographical objects have added layers of meaning to the novel through their absence as well as presence, and therefore they have become an integral part of the construction as well as meaning making of life narratives in the graphic novel.

\section{REFERENCES}

[1] Karpinski, J. B., (2001). Artifacts and Life Writing. In M. Jolly (ed.), The Encyclopedia of Life Writing: Autobiographical and Biographical Forms, (pp. 55-56). London: Fitzroy Dearborn Publishers.

[2] Novak, J., (2017). Experiments in Life Writing: Introduction. In L. Boldrini \& J. Novak (eds.), Experiments in Life Writing: Intersections of Auto/Biography and Fiction, (pp. 1-36). New York: Springer.

[3] Caruth, C. (1996). Unclaimed Experience: Trauma, Narrative and History, Maryland: John Hopkins University Press.

[4] Hirsch, M., (1997). Family Frames: Photography, Narrative and Postmemory, Harvard: Harvard University Press.

[5] Chute, H., \& Spiegelman, A., (2011). Why Mice? Retrieved from:

http://www.nybooks.com/blogs/nyrblog/2011/oct/20/whymice

[6] Kohli, P., (2012). The Memory and Legacy of Trauma in Art Spiegelman's Maus. The Journal of Historical Studies, 1 (1), pp. 1-22.

[7] Spiegelman, A., (1986). Maus I: A Survivor's Tale: My Father Bleeds History, New York: Pantheon Books.

[8] Spiegelman, A., (1992). Maus II: A Survivor's Tale: And Here My Troubles Began, New York: Pantheon Books.

[9] Chute, H., (2012). Comics as Archives: MetaMaus. On the Subject of Archives, 9, Retrieved from: http://hemisphericinstitute.org/hemi/en/e-misfercia-91/chut e

[10] Kolar, S., (2013). Intergenerational Transmission of Trauma in Spiegelman's Maus. Brno Studies in English, 39 (1), pp.227-241. 